MIDLAND CORE REPOSITORY

Quarterly Technical Progress Report

July 1, 1998-September 30, 1998

By

Noel Tyler

Report Issue Date: September 1998

Performed Under Contract No. DE-FG22-94BC14854

University of Texas @ Austin

Austin, Texas 


\section{DISCLAIMER}

This report was prepared as an account of work sponsored by an agency of the United States Government. Neither the United States Government nor any agency thereof, nor any of their employees, makes any warranty, expressed or implied, or assumes any legal liability or responsibility for the accuracy, completeness, or usefulness of any information, apparatus, product, or process disclosed, or represents that its use would not infringe privately owned rights. Reference herein to any specific commercial product, process, or service by trade name, trademark, manufacturer, or otherwise does not necessarily constitute or imply its endorsement, recommendation, or favoring by the United States Government or any agency thereof. The views and opinions of authors expressed herein do not necessarily state or reflect those of the United States Government.

This report has been reproduced directly from the best available copy. 


\section{DISCLAIMER}

Portions of this document may be illegible in electronic image products. Images are produced from the best available original document. 
$\mathrm{DOE} / \mathrm{BC} / 14854-10$

Distribution Category UC-122

\title{
Midland Core Repository
}

\author{
By \\ Noel Tyler
}

November 1999

Work Performed Under Contract No. DE-FG22-94BC14854

\author{
Prepared for \\ U.S. Department of Energy \\ Assistant Secretary for Fossil Energy
}

Chandra Nautiyal, Project Manager

National Petroleum Technology Office

P.O. Box 3628

Tulsa, OK 74101

\begin{abstract}
Prepared by
University of Texas @ Austin

Bureau of Economic Geology

Box X, University Station

Austin, TX 78713
\end{abstract}




$$
\begin{aligned}
& \text { Quarterly Technical Progress Report } \\
& \text { July } 1 \text { - September } 30,1998 \\
& \text { for }
\end{aligned}
$$

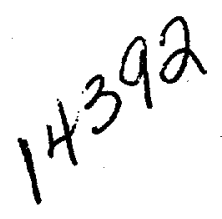

Midland Core Repository

Grant No. DE-FG22-94BC14854 - 10

\author{
Submitted by: \\ Bureau of Economic Geology \\ The University of Texas at Austin \\ Box $X$, University Station \\ Austin, Texas 78713
}

Grant Start Date:

Completion Date:

DOE Award for Federal Fiscal Year '99:

Principal Investigator:

Contracting Officer's Representative (COR):
September 1, 1994

August 31, 1999

$\$ 75,000$

Noel Tyler

Chandra Nautiyal 
Activities performed during the fourth quarter of Federal fiscal year 1998 are as follows:

\begin{tabular}{llccl}
\multicolumn{1}{c}{ Activity } & $\begin{array}{c}\text { Sample } \\
\text { Type }\end{array}$ & $\begin{array}{c}\text { No. of } \\
\text { Wells }\end{array}$ & $\begin{array}{c}\text { No. of } \\
\text { Boxes }\end{array}$ & User \\
Viewing & Core & 17 & 212 & Industry \\
Viewing & Cuttings & 0 & 0 & \\
Checkouts & Core & 1 & 1 & Industry \\
Checkouts & Cuttings & 13 & 22 & Industry
\end{tabular}

The water well problems has been solved by using a new filter system. We continue to repatriate core to various states. The next big shipment will be to Oklahoma. 